\title{
APLIKASI INSEKTISIDA NABATI BERBAHAN TANAMAN RAWA UNTUK MENGENDALIKAN HAMA KEDELAI ULAT GRAYAK (Spodoptera litura) DI LAHAN RAWA PASANG SURUT
}

(Application of Botanical Insecticides Made from Swamp Plants to Control Soybean Armyworms (Spodoptera litura) in Tidal Swamplands)

\author{
Asikin, S. ${ }^{1)}$, Melhanah ${ }^{2)}$ dan Lestari, Y. ${ }^{1)}$ \\ ${ }^{1)}$ Peneliti Balai Penelitian Pertanian Lahan Rawa \\ 2) Jurusan Budidaya Pertanian, Fakultas Pertanian, Universitas Palangka Raya \\ HP $082155755054 \quad$ Email : syaifulasikin1958@gmail.com
}

Diterima : $29 / 12 / 2020$

Disetujui : 10/3/2021

\begin{abstract}
One type of pest that often attacks soybean plant leaves in tidal swamplands is the armyworm pest. The intensity of leaf damage due to armyworm attack in tidal swamps ranges from 30-95\%, and can even lead to crop failure. In controlling pests in soybean plants in general, always rely on chemical insecticides. The use of these chemical insecticides has a negative impact on the environment. To overcome this, the control is directed towards environmentally friendly pest control by utilizing swamp plants as a botanical insecticide. The study used a randomized block design (RBD) with 3 treatments of swamp plant extracts (galam, kirinyuh, kepayang) and 3 controls, namely without control, botanical insecticide made from neem, chemical insecticide with the active ingredient kloraniliprol. The aim of this study was to obtain a swamp plant extract that could be used in controlling armyworm pests (Spodoptera litura). The results showed that the three types of swamp plants could be used as botanical insecticides in controlling armyworm pests, and has an effectiveness value above $70 \%$. The highest effectiveness of botanical insecticides was obtained at the age of 75 DAP, namely Galam (78.29\%), Kirinyuh (78.86\%) and Kepayang (78.85\%).
\end{abstract}

Keywords: Botanical insecticides, armyworms, tidal swamps, swamp plants.

\section{ABSTRAK}

Salah satu jenis hama yang sering menyerang daun tanaman kedelai di lahan rawa pasang surut adalah hama ulat grayak. Intensitas kerusakan daun akibat serangan hama ulat grayak di lahan rawa pasang surut berkisar antara 30-95\%, bahkan dapat menjadikan gagal panen. Dalam mengendalikan hama tanaman kedelai pada umumnya selalu bertumpu pada insektisida kimia. Penggunaan insektisida kimia tersebut berdampak negatif bagi lingkungan. Untuk mengatasi hal tersebut maka pengendalian di arahkan kepada pengendalian hama yang ramah lingkungan dengan memanfaatkan tanaman rawa sebagai insektisida nabati. Penelitian menggunakan Rancangan acak kelompok (RAK) dengan 3 perlakuan ekstrak tumbuhan rawa (galam, kirinyuh, kepayang) dan 3 kontrol yaitu tanpa pengendalian, insektisida nabati berbahan nimba, insektisida kimiawi dengan bahan aktif kloraniliprol. Penelitian bertujuan untuk mendapatkan ekstrak tanaman rawa yang dapat digunakan dalam mengendalikan hama ulat grayak (Spodoptera litura). Hasil penelitian menunjukkan bahwa ketiga jenis tumbuhan rawa tersebut dapat digunakan sebagai bahan insektisida nabati dalam mengendalikan hama ulat grayak, dan memiliki nilai efektivitas diatas $70 \%$. Efektivitas insektisida nabati tertinggi diperoleh pada umur 75 HST yaitu Galam (78,29\%), Kirinyuh (78,86\%) dan Kepayang $(78,85 \%)$.

Kata Kunci : Insektisida nabati, ulat grayak, rawa pasang surut, tanaman rawa

\section{PENDAHULUAN}

Kedelai merupakan salah satu bahan pangan yang penting setelah beras dan jagung, di samping sebagai bahan pakan dan industri olahan. Kedelai memiliki arti penting sebagai sumber protein nabati. Pada tahun 2013 produktivitas kedelai mengalami penurunan sebesar 0,03 kuintal/hektar. Penurunan 
produktivitas kedelai disebabkan oleh berbagai faktor, salah satunya adalah serangan hama dan penyakit yang dapat menyebabkan kerusakan tanaman sehingga dapat menyebabkan kerugian pada petani (Anonim, 2013; Marwoto, 2010).

Tanaman kedelai mempunyai banyak jenis hama yang menyerang. Salah satu jenis hama yang sering menyerang daun tanaman kedelai di lahan rawa khususnya lahan rawa pasang surut adalah hama ulat grayak (Spodoptera litura). Asikin (2017) melaporkan bahwa salah satu jenis hama yang sering dan sangat dominan menyerang pertanaman kedelai di lahan rawa pasang surut adalah hama ulat grayak, dengan intensitas serangan berkisar antara 30-95\%, bahkan dapat menyebabkan gagal panen.

Pengendalian hama secara tepat perlu didasari oleh pemahaman perkembangan populasi hama dan musuh alami serta kaitannya dengan fenologi tanaman. Pemahaman ini diharapkan waktu pengendalian dapat lebih tepat dan pemilihan insektisida sesuai hama sasaran, sehingga tidak timbul resistensi, resurgensi, terbunuhnya musuh alami, dan keracunan pada ternak dan bahkan manusia. Penggunaan pestisida nabati merupakan salah satu cara dalam menggantikan peran pestisida kimia (Mudjib et al., 2014). Beberapa tanaman diketahui dapat memberi efek mortalitas terhadap serangga, sehingga tanaman tersebut dapat digunakan sebagai alternatif insektisida nabati (Siahaya dan Rumthe, 2014).

Di lahan rawa ditemukan lebih dari seribu species tumbuhan yang dapat digunakan sebagai bahan pestisida nabati, pupuk organik, tanaman perangkap, penolak, biofilter, tanaman penyerap unsur beracun bagi tanaman (Asikin, 2012). Penelitian bertujuan untuk mengetahui keefektivan insektisida rawa galam (Melaleuca cajuputi), kirinyuh (Chromolaena odorata) dan tanaman Kepayang (Pangium edule) terhadap intensitas serangan hama ulat grayak (S.litura) pada tanaman kedelai di lahan rawa pasang surut sulfat masam.

\section{BAHAN DAN METODE}

Penelitian dilaksanakan di Desa Kolam Kiri Dalam, Kecamatan Barambai, Kabupaten Barito Kuala, Provinsi Kalimantan Selatan pada bulan Juli 2018-Januari 2019. Bahan dan alat yang digunakan dalam penelitian ini adalah tumbuhan rawa sebagai insektisida nabati terdiri dari daun galam, gulma kirinyuh,dan daun kepayang, kedelai varietas Anjosmoro, pupuk SP-18, $\mathrm{KCl}$, Urea, dolomit, insektisida kimia dengan bahan aktif Kloraniliprol, pelarut aseton $70 \%$, Tween 40 . Alat yang digunakan water bath (untuk pemadatan), gelas kaca, alat pengaduk, cangkul, pisau, parang, Knapsack sprayer dan peralatan pertanian lainnya.

\section{Rancangan Percobaan}

Penelitian disusun menggunakan Rancangan Acak Kelompok (RAK) dengan 3 perlakuan ekstrak tumbuhan rawa pasang surut dan ditambah dengan 3 perlakuan kontrol yaitu kontrol 1 (Tanpa Pengendalian), kontrol 2 (Insektisida Nabati berbahan Nimba) dan kontrol 3 (Insektisida Kimiawi dengan bahan aktif Kloraniliprol. (Tabel. 1). Masing masing perlakuan diulang sebanyak 5 (lima) kali sehingga keseluruhan terdapat 30 satuan percobaan.

\section{Pelaksanaan Penelitian}

Pengolahan lahan dimulai dengan pembersihan areal dari gulma dan sisa-sisa tanaman serta mencangkul sebanyak dua kali untuk menghancurkan bongkahan-bongkahan tanah, kemudian dilakukan penggemburan tanah sekaligus membuat petak-petak percobaan. Petak percobaan dibuat dengan ukuran $10 \mathrm{~m} \times 10 \mathrm{~m}$ (30 petak percobaan). Jarak antar petak kelompok adalah $1 \mathrm{~m}$ dan jarak antar petak perlakuan adalah $50 \mathrm{~cm}$, dan tinggi petak perlakuan adalah $30 \mathrm{~cm}$. Untuk mengurangi kemasam tanah diberikan dolomit dosis $2 \mathrm{t} \mathrm{ha}^{-1}$ pemberian dilakukan 2 minggu atau 15 hari sebelum tanam. Benih ditanam 3 biji per lubang, setelah tumbuh disisakan satu tanaman, ditanam dengan jarak tanam $40 \mathrm{~cm} \mathrm{x}$ $20 \mathrm{~cm}$. Pupuk yang diberikan adalah SP-18 dengan dosis $100 \mathrm{~kg} \mathrm{ha}^{-1}, \mathrm{KCl}$ dengan dosis 100 $\mathrm{kg} \mathrm{ha}^{-1}$, dan Urea dengan dosis $100 \mathrm{~kg} \mathrm{ha}^{-1}$. Pupuk SP-18, KCl, dan Urea diberikan pada waktu tanam kedelai. Pupuk Urea diberikan dua kali yaitu setengah dosis diberikan pada saat tanam yang dicampurkan dengan pupuk SP-18 dan $\mathrm{KCl}$, sedangkan pemberian kedua pada umur tanaman 30 hari setelah tanam. 
Tabel. 1. Tabel perlakuan

\begin{tabular}{llll}
\hline No. & Perlakuan & $\begin{array}{l}\text { Nama IImiah dan Bahan } \\
\text { Aktif }\end{array}$ & $\begin{array}{l}\text { Bagian tanaman } \\
\text { yang digunakan }\end{array}$ \\
\hline 1. & Tanaman Galam & M. cajuputi & Daun \\
2. & Gulma Krinyuh & C. odorata & Daun \\
3. & Tanaman Kepayang & P. edule & Daun \\
4. & Tanpa Pengendalian (Kontrol 1) & - & Air \\
5. & Insektisida Nabati (Kontrol 2) & Azadirachta indica A.Juss & \\
6. & Insektisida Kimiawi (Kontrol 3) & Kloraniliprol & \\
\hline
\end{tabular}

\section{Penyediaan Ekstrak Insektisida Nabati dan Aplikasi \\ Insektisida nabati dibuat dalam bentuk} ekstrak padat (paste) dengan cara merendam bahan daun tumbuhan segar ke dalam pelarut (aseton) dengan perbandingan setiap $1000 \mathrm{~g}$ bahan tumbuhan direndam dengan $5 \mathrm{~L}$ pelarut selama 48 jam. Setelah direndam selama 48 jam, kemudian disaring dan hasil saringan dievaporasi menggunakan vacum untuk menghasilkan residu. Hasil residu dimasukkan ke dalam cawan terbuka dan dipanaskan pada waterbath dengan suhu $50 \quad{ }^{\circ} \mathrm{C}$. Untuk membentuk ekstrak padat, pemanasan harus dilakukan selama 6 jam. Sebelum aplikasi, terlebih dahulu ekstrak padat dicampur dengan minyak Tween 40 dengan perbandingan 10:1 agar daya rekatnya pada tanaman lebih kuat dan penyebarannya merata pada permukaan tanaman. Pencampuran ekstrak padat dengan Tween 40 dilakukan pada plat kaca hingga merata kemudian dimasukkan air sedikit demi sedikit ke dalam gelas dan dicampur dengan air sebanyak $1000 \mathrm{ml}$ untuk setiap 1,5 g ekstrak padat (Wiratno dan Siswanto, 2012; Bahi et al., 2014). Aplikasi insektisida nabati dilakukan dengan Knapsack sprayer kapasitas tangki 16 L, dengan cara menyemprotkan bahan insektisida nabati pada masing-masing petak perlakuan. Aplikasi Insektisida dilakuan pada saat tanaman umur 2 minggu setelah tanam dengan selang waktu 2 minggu sekali penyemprotan. Adapun dosis yang digunakan $1 \mathrm{~g} \mathrm{~L}^{-1}$ air. Pengamatan intensitas serangan dilakuan pada umur 25, 50 dan 75 hari setelah tanam (HST).

\section{Variabel Pengamatan}

Setiap petak perlakuan diambil tanaman contoh sebanyak 10 rumpun tanaman petak ${ }^{-1}$. Variabel yang diamati adalah intensitas serangan hama ulat grayak (\%) yang diukur pada umur 25, 50 dan 75 HST dan efektivitas insektisida.

\section{Intensitas kerusakan daun}

Intensitas kerusakan daun akibat ulat grayak dihitung menggunakan rumus sebagi berikut (Kurnia et al, 2018):

$$
\mathrm{I}=\frac{\sum(\mathrm{ni} \text { x vi) }}{\mathrm{Z} \text { x V }}
$$

Keterangan:

I : Intensitas serangan/intensitas kerusakan daun

ni: jumlah daun dalam tiap kategori serangan

vi: Nilai skala dari tiap kategori serangan (04)

$\mathrm{V}$ : Jumlah daun yang diamati

Z: Nilai skala dari kategori serangan tertinggi Serangan ulat dihitung berdasarkan

metode skor:

$0=$ tidak ada serangan

$1=$ kerusakan daun mencapai $1-25 \%$

$2=$ kerusakan daun mencapai $26-50 \%$

$3=$ kerusakan daun mencapai $51-75 \%$

$4=$ kerusakan daun mencapai $76-100 \%$

\section{Efektivitas Insektisida}

Perhitungan efektivitas insektisida dilakukan untuk mengetahui persentase efektivitas yang dihasilkan suatu bahan aktif dalam mengendalikan hama. Data hasil pengamatan digunakan untuk menghitung efektivitas insektisida yang diuji dengan rumus Abbot (Ciba-Geigy, 1981) dalam Rahmawati dan Handoko (2011) yaitu:

Keterangan:

$$
E I=\left(\frac{C a-T a}{c a}\right) \times 100 \%
$$

$\mathrm{EI}=$ Efektivitas insektisida yang sedang diuji (\%)

$\mathrm{Ca}=$ Intensitas serangan pada petak kontrol setelah aplikasi insektisida 
$\mathrm{Ta}=$ Intensitas serangan pada petak perlakuan setelah aplikasi insektisida

Analisa Data. Data intensitas kerusakan daun oleh hama ulat grayak yang diperoleh dianalisis dengan analisa sidik ragam dan dilanjutkan dengan Uji jarak Berganda Duncan (DMRT) pada taraf 5\%.

\section{HASIL DAN PEMBAHASAN}

\section{Intensitas Kerusakan Daun oleh Hama Ulat grayak}

Pengamatan terhadap intensiatas kerusakan daun yang disebabkan oleh hama ulat grayak dilakukan pada umur 25,50 dan 75 HST. Pengamatan pertama pada umur 25 HST, intensitas serangan tertinggi adalah pada kontrol (tanpa pengendalian) yaitu 15,5\%, sedangkan pada perlakuan lainya intensitas serangan berkisar antara 4,5-5,5\%. Pengamatan kedua pada 50 HST terjadi peningkatanan intensitas serangan hama ulat grayak pada semua perlakuan, tetapi pada perlakuan insektisida nabati ekstrak daun galam intensitas serangan yang terjadi hanya $14,5 \%$, perlakuan ekstrak daun kirinyuh $13,5 \%$ dan ekstrak daun kepayang $12,5 \%$ pada kontrol nabati (ekstrak daun nimba) $17,5 \%$ dan pada kontrol kimiawi $12,5 \%$ sedangkan pada perlakuan kontrol (tanpa pengendalian) menunjukkan intensitas serangan tertinggi yaitu $42,5 \%$. Peningkatan intensitas serangan hama ulat grayak terjadi pada semua perlakuan hingga pengamatan umur 75 HST, namun secara uji statistik pada perlakuan ekstrak insektisida nabati dan perlakuan insektisida kimia tidak menunjukkan adanya perbedaan yang nyata kecuali dengan perlakuan kontrol (tanpa pengendalian) itensitas serangan nyata lebih tinggi (Tabel 2).

Rendahnya tingkat serangan hama ulat grayak pada perlakuan insektisida nabati dari ekstrak daun galam diakibatkan oleh adanya senyawa volatil dan zat kimia yang dikandung oleh daun tanaman galam tersebut. Tumbuhan galam (M. cajuputi) merupakan jenis tumbuhan yang banyak tumbuh pada lahan rawa pasang surut sulfat masam, tumbuhan galam termasuk famili Myrtaceae merupakan indikator lahan rawa pasang surut sulfat masam, dan tumbuhan tersebut dapat digunakan sebagai pestisida nabati. Menurut Asikin dan Thamrin (2006), bahwa hasil penelitian pendahuluan ekstrak daun galam dapat digunakan sebagai bahan pestisida nabati dalam mengendalikan hama seperti ulat jengkal, ulat grayak. Ekstrak daun galam juga dapat membunuh larva ulat jengkal, ulat buah paria, dan larva penggerek batang padi.

Pada ekstrak daun galam diperoleh senyawa trans caryophyllena, $\beta$ - Selinena, germacrena $\left(\mathrm{C}_{15} \mathrm{H}_{26} \mathrm{O}\right), \quad$ neopitadiena, sikloheksakarboksaldehida, 3,3,6,9,9pentametil-2,10-diaz, eEtanona 1-(4,6dihidroxy), dan stigmast-5-en-3-ol (Asikin, 2005). Minyak atsiri yang dihasilkan oleh tumbuhan galam juga mengandung 1,8-sineol, linalool, alfa-terpineol, terpinen-4-ol, terpinil asetat, pinena, nerolidol, leavo-pinena, farnesol, fitol, squalena, allaromadendrena, ledena, palustrol, viridiflorol, ledol, betulinaldehid, asam betulinat, asam platanat, limonena, dipentena, azulen, sesquiterpen, valerianik aldehid dan benzaldehid (Widiyanto \& Siarudin, 2013). Diduga adanya kandungan alkaloid dan terpenoid tersebut mengakibatkan hama ulat grayak tidak menyukai daun galam tersebut. Hal ini sesuai pendapat Schoonhoven (1982) alkaloid dan terpenoid sangat berpotensi sebagai penghambat makan pada sejumlah serangga. Senyawa anti makan efektif bila dapat menghambat makan sekitar 80-100\%.

Kirinyuh $(C$. odorata $)$ merupakan tumbuhan semak berkayu yang berperan sebagai gulma invasif, yang juga dikenal sebagai gulma Siam. Kirinyuh ini cukup efektif dalam mengendalikan hama perusak tanaman seperti ulat grayak, ulat jengkal, ulat kubis dan ulat buah (Asikin dan Thamrin 2005; Asikin 2015). Menurut Hadi (2008), sifat toksik ini disebabkan oleh senyawa bioaktif yang terkandung dalam ekstrak daun kiriyuh seperti terpenoid, tanin, saponin, fenol, dan alkaloid yang terdapat pada tumbuhan merupakan bahan aktif sebagai pengendali hama. Senyawa bioaktif seperti saponin dan tanin dapat menyebabkan mekanisme penghambat makan. Lebih lanjut Udebuani et al. (2015) juga menjelaskan bahwa saponin adalah kelompok metabolit sekunder tumbuhan dengan sifat biologis beragam, seperti antifeeding dan dapat menghambat pertumbuhan. 
Tabel 2. Rata rata intensitas kerusakan daun kedelai (\%) oleh hama ulat grayak di lahan Rawa Pasang surut.

\begin{tabular}{lllrrr}
\hline No. & Perlakuan & Nama & \multicolumn{3}{c}{ Intensitas Kerusakan Daun (\%) } \\
& & Daerah & 25 HST & $50 \mathrm{HST}$ & $75 \mathrm{HST}$ \\
\hline 1. & Melaleuca cajuputi & Galam & $5,0 \mathrm{~b}$ & $14,5 \mathrm{~b}$ & $19,0 \mathrm{~b}$ \\
2. & Chromolaena odorata & Kirinyuh & $4,5 \mathrm{~b}$ & $13,5 \mathrm{~b}$ & $18,7 \mathrm{~b}$ \\
3. & Pangium edule & Kepayang & $5,0 \mathrm{~b}$ & $12,5 \mathrm{~b}$ & $18,5 \mathrm{~b}$ \\
4. & Kontrol II (Insektisida Nabati) & Nimba & $5,5 \mathrm{~b}$ & $17,5 \mathrm{~b}$ & $20,5 \mathrm{~b}$ \\
5. & Kontrol I (air) & - & $15,5 \mathrm{a}$ & $42,50 \mathrm{a}$ & $87,5 \mathrm{a}$ \\
6. & Kontrol III (insektisida bahan & - & $4,5 \mathrm{~b}$ & $12,5 \mathrm{~b}$ & $16,5 \mathrm{~b}$ \\
& aktif Kloraniliprol) & & & & \\
\hline
\end{tabular}

Keterangan : Angka angka yang diikuti oleh huruf yang sama pada setiap umur pengamatan menunjukkan tidak berbeda nyata menurut uji DMRT pada taraf 5\%.

Tabel 3. Efektivitas Insektisida nabati perlakuan (\%) berdasarkan data Intensitas kerusakan daun pada kontrol perlakuan Nimba, air dan insektisida sintetik

\begin{tabular}{llllll}
\hline No. & Perlakuan & Nama & \multicolumn{3}{c}{ Efektivitas Insektisida (\%) } \\
\cline { 3 - 6 } & & Daerah & 25 HST & 50 HST & 75 HST \\
\hline 1. & Melaleuca cajuputi & Galam & 67,74 & 65,88 & 78,24 \\
2. & Chromolaena odorata & Kirinyuh & 70,96 & 68,24 & 78,86 \\
3. & Pangium edule & Kepayang & 67,74 & 70,59 & 78,85 \\
4. & Kontrol II (Insektisida nabati) & Nimba & 64,52 & 58,83 & 76,57 \\
5. & Kontrol III (Insektisida Kimiawi) & ba. Kloraniliprol & 70,97 & 70,59 & 81,14 \\
6. & Kontrol I (air) & - & - & - & - \\
\hline
\end{tabular}

Asikin et al. (2013), melaporkan bahwa tumbuhan kepayang (P.edule) mengandung beberapa komponen kimia asam sianida dan piretrin yang pada konsentrasi tinggi dapat pembunuh serangga. Senyawa piretrin bekerja dengan cara mengganggu jaringan saraf serangga. Menurut Wiryadiputra, et al. (2014) tumbuhan kepayang mengandung senyawa asam sianida, flavanoid dan saponin sehingga berpotensi sebagai larvasida.

\section{Efektivitas Insektisida Nabati dalam mengendalikan Ulat grayak}

Insektisida nabati tumbuhan rawa yang diujikan terhadap serangan hama ulat grayak pada tanaman kedelai di lahan rawa pada umur $25,50,75$ HST menunjukkan kisaran efektivitasnya antara $65,88-78,86 \%$, insektisida nimba kisaran efektivitasnya 58,83-76,57\%, sedangkan insektisida kimiawi berbahan aktif (ba) Kloraniliprol kisaran efektivitasnya 70,5981,14\% (Tabel 3).

Bila dilihat berdasarkan efektivitasnya ketiga insektisida tumbuhan rawa lebih baik dibanding dengan insektisida nimba, dan sedikit lebih rendah efektivitasnya dibanding insektisida kimiawi Kloraniliprol. Ketiga insektisida nabati dari bahan Galam, Kirinyuh dan Kepayang pada umur pengamatan 75 HST juga efektif mengendalikan hama ulat grayak dengan nilai efektivitas insektisida sebesar $>78 \%$. Hal ini sesuai dengan pendapat Rizal et al. (2011) suatu formulasi insektisida dikatakan efektif bila tingkat efektivitas insektisida tersebut $\geq 70 \%$, sedangkan menurut Rohimatun dan Laba (2013) pestisida nabati dikatakan efektif bila efektivitas pengendalian > $50 \%$.

\section{KESIMPULAN}

Dari penelitian ini dapat disimpulkan bahwa ekstrak tanaman Galam, Kirinyuh dan Kepayang efektif dalam mengendalikan hama ulat grayak atau hama pemakan daun kedelai lainnya dan tidak menunjukkan adanya perbedaan dengan perlakuan kontrol insektisida Kloraniliprol. Efektivitas insektisida nabati tertinggi diperoleh pada umur 75 HST yaitu Galam (78,29\%), Kirinyuh (78,86\%) dan 
Kepayang (78,85\%). Dengan demikian ketiga insektisida nabati tumbuhan rawa tersebut dapat digunakan untuk mengendalikan hama-hama pemakan daun tanaman kedelai.

\section{DAFTAR PUSTAKA}

Anonim, 2013. Berita Resmi Statistik No. 45/07/Th.XVI. Badan Pusat Statistik: Jakarta

Asikin S. 2005. Pengujian ekstrak tanaman galam (Melaleuca cajuputi) terhadap hama ulat grayak (Spodoptera litura F.). Kegiatan Hama Penyakit Balai Penelitian Pertanian Lahan Rawa. Balai Penelitian Pertanian Lahan Rawa. 8p.

Asikin, S., dan M. Thamrin. 2006. Pengendalian hama serangga sayuran ramah lingkungan dan di lahan rawa pasang surut. Dalam M. Noor., Izzuddin, $\mathrm{N}$ dan S.S. Antarlina $(E d s)$. Sayuran Di Lahan Rawa: Teknologi Budidaya dan Peluang Agribisnis. Balai Besar Penelitian dan Pengembangan Sumber Daya Lahan Pertanian. Balai Penelitian Pertanian Lahan Rawa (Monograf). Hal:73 - 86.

Asikin, S., Cahyana D., dan Thamrin, M. 2013. Hama pun Mabuk Kepayang. [Online] http://balittra.litbang.pertanian.go.id/inde x. [16 Mei 2016]

Asikin, S. 2012. Uji efikasi ekstrak tumbuhan rawa untuk mengendalikan hama ulat grayak skala laboratorium. Jurnal Agroscientiae, 19(8): 178-183.

Asikin, S. 2015. Efektivitas ekstrak tumbuhan sebagai insektisida nabati terhadap hama ulat grayak (Spodoptera litura F.). Jurnal Agroscientiae, 22(1): 22-29.

Asikin, S. 2017. Serangga hama utama pemakan daun kedelai di lahan rawa. Laporan Kegiatan Hama-Penyakit. Balai Penelitian Pertanian Lahan Rawa. 9 hlm.

Bahi, M., Mutia, R., Mustanir dan Endang, L. 2014.Bioassay on n-hexane extract of leaves Cassia alata against Candida albicans. J. Natural, 14(1):5-10.

Hadi, M. 2008. Pembuatan kertas anti rayap ramah lingkungan dengan memanfaatkan ekstrak daun kirinyuh (Eupatorium odoratum). Jurnal Bioma, 6(2):12-18.
Marwoto, 2010. Prospek Parasitoid Trichogrammatoidea bactrae-bactrae Nagaraja (Hymenoptera) sebagai Agens Hayati Pengendali Hama Penggerek Polong Kedelai Etiella spp. Jurnal Pengembangan Inovasi Petanian, 3(4), 274-288. Balitkabi, Malang.

Mudjib, A.M., Ana Syabana dan Dewi Hastuti. 2014. Uji efektivitas larutan pestisida nabati terhadap hama krop (Crocidolomia pavonana L.) pada tanaman kubis (Brassica oleraceae). Jurnal Ilmu Pertanian dan Perikanan, 3(1) : $67-72$.

Kurnia Paramita,S.K., Gatut Wahyu, A. S., Heru Kuswantoro. 2018. Intensitas serangan ulat grayak Spodoptera litura F. pada genotipe kedelai. Dalam Herdina Pratiwi (Ed.) Prosiding Seminar Hasil Penelitian Tanaman Aneka Kacang dan Umbi 2017. Hal 258-266. Pusat Penelitian dan Pengembangan Tanaman Pangan, Bogor. 8 Juni 2018

Rahmawati, D dan Handoko, H. 2011. Pengujian lapangan efikasi insektisida profenofos 500

g/l terhadap hama ulat grayak Spodoptera exigua Hbn. Pada tanaman bawang merah. Balai Pengkajian Teknologi Pertanian. Jawa Timur. Hlm 303-308.

Rizal, M., Laba, I.W., Mardiningsih, T.L., Darwis, M., Sugandi, E., Sukmana, C. 2011. Pemanfaatan pestisida nabati untuk menurunkan serangan hama wereng coklat Nilaparvata lugens pada padi $>80 \%$. Laporan teknis penelitian. Balai Penelitian Tanaman Rempah dan Obat. Malang.

Rohimatun dan Laba, I.W. 2013. Efektivitas insektisida minyak serai wangi dan cengkeh terhadap hama pengisap buah lada (Daynus piperis China). Bul. Tanaman Obat dan Rempah, 24 (1):2634.

Schoonhoven LM. 1982. Biologica 1 a spects of antifeedant. Ent. Exp. \& Appl. 31: 57-69.

Siahaya, V.G., dan. Rumthe, R.Y. 2014. Uji ekstrtak daun pepaya (Carica papaya) terhadap larva Plutella xylostella (Lepidoptera: Plutellidae). Jurnal Ilmu 
Budidaya Tanaman Agrologia, 3(2): 112116.

Udebuani, A.C., Abara, P.C., Obasi, K.O., and Okuh, S.U. 2015. Studies on the insecticidal properties of Chromolaena odorata against adult stage of Periplaneta Americana. Journal Entomology and Zoology Studies, 3(1):318-321

Widiyanto, A. dan Siarudin, M. 2013. Karakteristik daun dan rendemen minyak atsiri lima jenis tumbuhan kayu putih. Jurnal Penelitian Hasil Hutan, 31(4): 235-241.

Wiratno dan Siswanto. 2012. Bioassay insektisida nabati berbasis tanaman jarak pagar dan cengkeh terhadap Nilaparvata lugens Stal. Dalam Prosiding Seminar Minyak Atsiri, Solok. Prosiding Seminar Nasional Tanaman Atsiri. Solok, 11-12 Juli 2012. Badan Litbang Pertanian.

Wiryadiputra, S., Rusda ,I., Iis, NA. 2014., Pengaruh Ekstrak Tanaman Picung (Pangium edule) sebagai Pestisida Nabati Terhadap Mortalitas Penggerek Buah Kopi. Bul. Pelita Perkebunan, 30(3): 220-228 